\section{Kustamonu Eğitim Dergisi Kastamonu Education Journal}

Temmuz 2019 Cilt:27 Sayı:4

kefdergi.kastamonu.edu.tr
Başvuru Tarihi/Received: 12.06.2018

Kabul Tarihi/Accepted: 14.08 .2018

DOI: $10.24106 /$ kefdergi.3150

\title{
Hemşirelik Eğitiminde Altı Şapkalı Düşünme Tekniğinin Kullanımı: İki Farklı Tekniğin Karşılaştırılması
}

\section{Nursing Education Method In The Use Of The Six Thinking Hats: Comparison Of Two Different Techniques}

\section{Öz}

\author{
Nilay ÖZKÜTÜK ${ }^{1}$, Fatma ORGUN²${ }^{2}$, Hale SEZER ${ }^{3}$
}

Öğrenciler her gün basit ya da zor birçok karar vermektedirler. Bu zor kararları vermeye çalışırken, düşünülmüş kararlara varmada tüm adımları düşünmeyi sıkça başaramamaktadırlar. Altı şapkalı düşünme tekniği, zor yaşam kararlarını vermede çeşitli görüşlerden yararlanma ve düşünmede öğrencilere yardım etmektedir. Amaç: Hemşirelik eğitiminde alt şapkalı düşünme tekniği ile düz anlatım tekniği karşılaştırılarak öğrenci hemşirelerin öğrenme başarısına hangi tekniğin daha etkili olduğunun belirlenmesi amaçlanmıştır. Yöntem: Ön test, son test kontrol gruplu deneme modeline göre yarı deneysel olarak gerçekleştirilen araştırma kapsamına, bir hemşirelik fakültesinde öğrenim gören birinci sınıf öğrencilerinden araştırmaya katılmayı kabul eden öğrenciler alınmıştır ( $n=126)$. Araştırma verileri, "Tanıtıcı Bilgi Formu" ve "Sağlığı Geliştirme" konusunda araştrrmacılar tarafindan ilgili literatür doğrultusunda hazırlanan bilgi testleri ön-test, son-test kullanılarak toplanmıştır. Verilerin analizinde, sayı, yüzde dağılımları ve t-testi yapılarak değerlendirilmiştir. Bulgular: Deney grubunun son test puan ortalaması 58,09 $\pm 18,09$ ile kontrol grubunun son test puan ortalaması 51,98 $\pm 14,32$ bulunmuştur. Deney ve kontrol grubunun son test puan ortalamaları arasında istatistiksel olarak anlamlı bir fark olduğu belirlenmiştir $(p<0.05)$. Öğrenciler, Alt Şapkalı Düşünme tekniğinin farklı, eğlenceli, zevkli olduğunu ifade etmişlerdir. Sonuçlar: Altı şapkalı düşünme tekniğinin başarıyı geleneksel yöntemlere göre daha çok arttırdığı sonucuna varılmıştı. Ayrıca, çalışmanın hemşirelik öğrencilerinin kritik düşünme yeteneklerinin gelişmesi için önemli olan yaratıcı eğitim yönteminin kullanımının test edilmesi açısından da önemli olduğu düşünülmektedir.

Anahtar Kelimeler: alt şapka tekniği, düz anlatım tekniği, öğrenci hemşire

\section{Abstract}

Student nurses every day, give many decided a simple or difficult. This teaching technique is helping for student nurses to give difficult decisions in life with thinking and using a variety of opinions. Aim: This study compared to the six hat thinking technique, the student lecturing technique of nurses in terms of learning achievement was conducted to determine which technique is more effective and permanent. Method: In the quasi-experimental study with pre-test and post-test control group, students who were accepted to participate in the survey were selected from the first-year students who were studying at a faculty of nursing $(n=126)$. Research data, "Information Form" and "Health Promotion" by the researchers in the information prepared in accordance with the related literature testing the pre-test and post-testing were collected using. Analysis of the data, number, percentage and research findings were evaluated and compared by t-test. Results: The Post-test score of the experimental group was 58,09 $\pm 18,09$ and the post-test score of the control group was $51,98 \pm 14,32$. It was determined that there was a statistically significant difference between the experimental and control group's final test scores $(p<0.05)$. Students expressed that The Six Thinking Hats technique was different, fun, and enjoyable. Conclusion: The result was that the six- thinking hat technique increased the success more than traditional methods. It is also believed that the study is important in terms of testing the use of creative instruction that is crucial to the development of critical thinking skills of nursing students.

Keywords: six thinking hats technique, lecturing technique, nursing student

\footnotetext{
1. Ege Üniversitesi, Hemşirelik Fakültesi, Izmir, Türkiye; https://orcid.org/0000-0003-1405-4600

2. Ege Üniversitesi, Hemşirelik Fakültesi, İmir, Türkiye; https://orcid.org/0000-0002-2351-7227

3. Ege Üniversitesi, Hemşirelik Fakültesi, Izmir, Türkiye; https://orcid.org/0000-0003-4199-7727

Atıf / Citation: Özkütük, N., Orgun, F., \& Sezer, H. (2019). Hemşirelik eğitiminde alt şapkalı düşünme tekniğinin kullanımı: İki farklı tekniğin karşılaştrııması. Kastamonu Education Journal, 27(4), 1553-1562. doi:10.24106/kefdergi.3150
} 


\section{Extended Abstract}

Aim: In order to train individuals as interrogators and researchers, it is necessary to use methods of developing critical and creative thinking in learning-teaching environments. It helps to investigate innovations using creative thinking, or to develop new solutions to past problems. The creative way of thinking creates original thoughts. Today, the half-life of information is greatly reduced and it needs to be used in education systems that provide creative thinking in order to produce new information and to develop it. Creative thinking is a productive process. This process is used in educational programs as a philosophy, enabling the student to find ideas and to find a logical reason in the debate environment and defend and develop his ideas. The creative thinking techniques to improve students' decision-making skills enable them to take a holistic view of events. In the decision-making process, which is difficult for the students, it is necessary to take a different view of the situation and make the right decision to reach the best result. This can be improved by the Six-hat thinking technique. The six-hat thinking technique allows you to take advantage of opinions and thoughts with different perspectives. Nurses care for the illness; they should be able to develop different opinions and suggestions while giving care to them from a holistic viewpoint. This study was carried out in order to determine which technique is more effective for the learning success of the student nurses by comparing the expression technique with six hat thinking techniques in nursing education.

Method: Pre-test post-test was performed according to control group semi-experimental model. Within the scope of the study, students who were accepted to take part in the research were included in a university nursing first year student $(n=126)$. It was determined that the students with single school numbers will be tested with the unanimous assignment method and the students with double numbers will form the control group. Experimental group; the group prepared according to the six-hat thinking technique and the classroom environment were organized. The control group was; the course was taught by the traditional method of education (lecturing, question-answer, etc.). The research data were obtained from the "Information Form" given at the beginning and end of the study and the "Health Promotion" course prepared by the researchers in pre-test and post-test in accordance with the related literature, using an achievement test consisting of 15 open-ended and multiple choose questions. In addition, a structured questionnaire consisting of 20 questions was used by the students in the experimental group to receive feedback on the six hat thinking techniques. In the analysis of the data, sociodemographic data and opinions on the intervention of the Six-Hat Thinking Technique were analyzed using t-test to evaluate the pretest posttest comparisons between groups.

Results: $81.7 \%$ of the students who participated in the research are females. A statistically significant difference was found between pre-test and post-test scores of the experimental and control group students $(p<0.05)$. The post test scores of the students in the experimental group were found to be higher than control group. It was determined that there was a statistically significant difference between the test and control group mean post test scores $(p<0.05)$. With the Six-Hat Thinking Technique, the question of how to solve a problem from different point of view has been discussed and concepts have been derived. The statements of the students at the highest level; "To notice the positive and negative aspects of the cause (93,7\%) "," Provided different ideas and ideas to share $(\% 92,1)$ "," I contributed to the development of my creativity $(93,7)$ "," By keeping away from memorization, I obtained the permanence of the information I obtained $(93,7 \%)$ ". The sentence that the students participate at the lowest level is; "Empathy has become sympathetic and has affected me badly $(12,7 \%)$ ", "Especially black hat activity (negative) made me pessimistic" $(22,2)$. It has been seen that the concepts specific to each hat have emerged either positively or negatively. The students have stated that Six-Hat Thinking Technique is different, fun and enjoyable.

Conclusion: The development of students' learning ability to look from different frames as well as an event, to be aware of their feelings and to develop critical thinking skills, the use of the six-hats thinking technique so it can provide a holistic care to patients is important in nursing education. 


\section{Giriş}

Toplumların yapısı, bilim ve teknolojiden etkilenerek değişmektedir. Toplumun yapısını değiştiren bilim ve teknoloji eğitim sistemlerini de değiştirmektedir. Son yıllarda yaratıcı, eleştirel düşünen bireylerin gelişmesini sağlamak amacıyla öğrenci merkezli yaklaşımlar tercih edilmektedir. Öğrenci merkezli yaklaşımlarla ilgili yapılan çalışmalarda, öğrencilerin kendi öğrenme becerilerini geliştirdiği, yeni öğrenme stratejilerini denediği, eğitim sürecinde daha aktif olduğu ve öğrenmenin daha kalıcı olduğu saptanmıştır (Aybek, 2007). Öğrencilerin araştırmacı ve sorgulayan olmalarını sağlamak amacıyla öğrenme ortamında değişiklik yapılması gerekmektedir. Öğrenme ortamını, öğrencilerin özgürce fikirlerini paylaşabilecekleri, durumları eleştirel olarak düşünebilecekleri ve yaratıcı olabilecekleri şekilde düzenlenmesi önemlidir. Eleştirel düşünme becerisi ile problem çözme adımları gerçekleştirilerek yaratıcı düşünme desteklenebilmektedir (Daly,1998; Büyükdokumacı ve Baştürk, 2010).

Yaratıcı düşünme, buluş yolu ile öğrenmeyi geliştiren, yeni fikirlerin üretilmesini sağlayan ya da eski problemlere yeni çözümler geliştirilmesini sağlayan bir düşünce biçimidir. Yaratıcı düşünme bilginin üretilmesi sürecinde özgür düşünmeyi sağlamaktadır. Öğrencinin fikir bulması ve tartışma ortamlarında mantıkı nedenler bularak fikirlerini savunmasını ve geliştirmesini sağlayarak bir ürün ortaya konmasını sağlayan bu süreç, bir felsefe olarak eğitim programlarında kullanılmaktadır (Koray, 2004; Wegerif, 2007; Yenilmez ve Yolcu, 2007). Öğrenciler her gün basit ya da zor birçok karar vermektedirler. Bu zor kararları vermeye çalışırken, düşünülmüş kararlara varmada tüm adımları düşünmeyi sıkça başaramamaktadırlar. Alt Şapkalı Düşünme tekniği, zor yaşam kararlarını vermede çeşitli görüşlerden yararlanma ve düşünmede öğrencilere yardım etmektedir (Goebel ve Seabert, 2006).

Alt Şapkalı Düşünme tekniğinde, durumlara farklı bakış açılarıyla bakmak gereklidir. Bu teknik ile olumlu ve olumsuz duygulardan mantıklı düşünmeye kadar; yaratıcılığı geliştirmek için bilgi birikimlerinden uzaklaşarak çok yönlü düşünme gerçekleşmektedir. Düşünce şapkaları altı farklı yapıda ve bunlara uygun karekteristik rollerle her biri farklı renktedir. Öğrencilerin her şapka değişiminde, o şapkanın renginin ifade ettiği düşünce gözüyle durumu analiz ederek düşünebilmesi çok önemlidir. Bu teknik ile düşünce kalıplarının yıkılması sağlanarak, olayları çok yönlü değerlendirebilmeleri sağlanmak ve tek yönlü düşünmelerini engellemektir. Farklı bakış açılarıyla değerlendirilen durum, kişilerin en doğru kararı vermesini sağlamaktadır (Erginer, 2000; De Bono, 2006). Altı Şapkalı Düşünme tekniğindeki şapkalar, farklı düşünme türlerinden oluşmaktadır. Kolay ve eğlenceli olan bu teknik, öğrenciler tarafindan da kolay adapte olmalarını sağlayarak öğrenmenin daha olumlu bir ortamda sağlanmasına neden olmaktadır. Öğrencilerin farklı düşünme tarzlarına sahip olmaları açııından yararlı olmakla birlikte davranış kazanma, diğer öğrenciler ile birlikte problem çözme becerilerini geliştirmede de önemli sonuçlar elde edildiği saptanmıştır (Can ve Semerci, 2007).

Bu teknikteki şapkaların renkleri birbirinden farklıdır. Bu renkler; beyaz, kırmızı, siyah, sarı, yeşil ve mavidir. Şapkaların renkleri bireylerin akıllarında bir takım duygu ya da durumu canlandırmasını kolaylaştırdığı için kullanılmaktadır. Bu teknikle, kişinin olumlu ya da olumsuz düşünmesi, eleştirel, yaratıcı olması ya da duygusal bir tepki vermesi sağlanmış olur. Renkler ile şapkaların işlevleri şöyle özetlenebilir; (Erginer, 2000; De Bono, 2006)

Beyaz şapka: Tarafsız ve objektifliği göstermektedir. Net bilgiler istenir. Niceliksel ispatlar sunar. Beyaz şapka ile düşünürken, niceliksel tarafıızık ve objektiflik ortaya konulması açısından kolay bir şapkadır. Bu şapka takılıyken yorumlamalardan kaçınılır net bir şekilde durum analiz edilir. Buradaki amaç net bilgiye ulaşmaktır. Kişisel fikirlerin geliştirilmesi ya da duygusal olunması beklenmez (Koray, 2004; Can ve Semerci, 2007; De Bono, 2006).

Kırmııı şapka: Kırmızı renk öfke, tutkuyu akla getirmektedir. Bu şapka da duygusallık önemlidir. Duygusal fikirler ortaya atlır (Berber ve ark., 2002; Koray, 2004). Buradaki amaç, durumu analiz ederken kişinin bireysel fikirlerini ve duygularını keşfetmesini sağlamaktır (Can ve Semerci, 2007).

Siyah şapka: Siyah renk karamsarlık ve olumsuzluğu çağrıştırmaktadır. Bu şapka ile kötümser düşünceler keşfedilir ve olumsuz manttk devrededir. Olumsuzluk ağır basan bir şapkadır. Diğer bir ifadeyle "eleştirme şapkası" dır. Eleştirme şapkası olmasına rağmen taraf tutulmaz ve tartş̧ma ortamı yaratılmaz (Berber ve ark., 2002; Koray, 2004; De Bono,2006).

Sarı şapka: Aydınlık ve olumlu bir şapkadır. Güneş’in aydınlığı gibi düşünülür. Sarı şapka siyah şapkanın tam tersidir. Bu şapka takılıyken olumlu düşünceler düşünülür. İyimser ve faydalı olmaya odaklanma önemlidir. Bu şapkada yapıcı düşünce ön plandadır (Berber ve ark., 2002; Koray, 2004). Sarı şapka düşünmesinde amaç; yararlı düşüncelerin saptanması ve saptanan bu fikirlerin sağlam gerekçelerle sunulması önemlidir (Can ve Semerci, 2007; De Bono, 2006).

Yeşil şapka: Bitkilerin küçük tohumlardan gelişmesini çağrıştırarak üretken fikirlerin sunulmasını sağlayan şapkadır. Bu nedenle, yeşil renk özellikle yaratıcılıkla ilgili olan düşünme şapkasını simgelemesi için seçilmiştir. Bu renk ile yeni fikirlerle ve yeni bakış açıları ile durum analiz edilir. Yeni fikirlerin üretilmesi amaçlanan bu şapka ile alternatif çözüm 
yolları ya da durumlar araştırılır ve yeni fikirler üretilir (Koray, 2004; Can ve Semerci, 2007).

Mavi şapka: Kontrol şapkası olarak da adlandırılan mavi şapka gökyüzünün rengi yani her şeyin üstündeki renk olarak ifade etmektedir (Berber ve ark., 2002; Koray, 2004). Mavi şapka adeta bir orkestra şefi gibi hem kendisine hem de diğer şapkalara, düşünme şapkalarından hangisine geçileceğine karar vererek geçilmesini sağlar. Düşünme süreçlerini dikkatli bir şekilde gözlemler, her şapkanın kendi kuralına dikkat edilmesinde görev alır. En önemli rolü, her şapkanın kendi renginde o düşünce yapısına odaklanmalarını sağlamaktır (Can ve Semerci, 2007).

Alt şapkalı düşünme tekniği kullanılırken bazı özelliklere dikkat edilir. Bir şapka birden fazla kez kullanılabilir. Her bir yeni öneri için tekrar tekrar takılabilir. Şapkalar takılırken sarı şapkanın olumlu özelliği nedeniyle olumsuz özelliğe sahip olan siyah şapkadan önce takılması gerekmektedir. Bunun nedeni olaraksa, olumsuzu düşünmek ve dezavantajları saptamak olumlu düşünmekten daha kolay olmasıdır. Teknikte tarafsızlığın olması uygulamayı kolaylaştırmaktadır. Özgürce fikirler üretilip çürütülebilmektedir. Kuralları tanımlanmış bir oyunmuş gibi teknik eğitim ortamlarında rahatça kullanılabilmektedir (Koray, 2004; Karadağ ve ark., 2006).

Hastalara bakım veren hemşirelerin, sezgilerini kullanmaları, yaratıcı düşünebilmeleri, durumları duygusallıktan manttklı olumlu ya da olumsuz fikirler olarak değerlendirebilmeleri açısından güçlendirilmeleri ve cesaretlendirilmeleri gerekmektedir. Hemşirelerin yaşam boyu öğrenen, hastaya holistik bakış açısıyla bakabilen, bilgiyi kullanabilen yeni bilgiler üretebilen olabilmeleri ve eleştirel bakış açısı kazanabilmeleri için yaratıcı düşünme becerilerinin geliştirilmesi gerekmektedir. Buradan yola çıkarak bu çalışma, hemşirelik eğitiminde alt şapkalı düşünme tekniği ile anlatım tekniği karşılaştırılarak öğrenci hemşirelerin öğrenme başarısına hangi tekniğin daha etkili olduğunun belirlenmesi amacıyla gerçekleştirilmiştir.

\section{Yöntem}

\section{Amaç}

Hemşireler bakım verdiği hastalara sezgilerini kullanmalarını önermeli, hayal güçlerini geliştirebilecekleri ve düşünce üretebilecekleri konusunda cesaretlendirmeli, enerjilerini kullanmalarına firsat vermelidir. Hemşirelik öğrencileri de mezun olduklarında bunları yapabilmek için, yaşam boyu öğrenmek, profesyonel olarak gelişebilmek, başkaları ile etkili çalışabilmek, hedeflenen sonuçlara ulaşmak, toplumu değiştirmek ve kültürler arası realiteyi geliştirmek için eleştirel ve yaratıcı düşünmek zorundadırlar. Buradan yola çıkarak bu çalışma, hemşirelik eğitiminde alt şapkalı düşünme tekniği ile düz anlatım tekniği karşılaştırılarak öğrenci hemşirelerin öğrenme başarısına hangi tekniğin daha etkili olduğunun belirlenmesi amacıyla gerçekleştirilmiştir.

Ön test, son test kontrol gruplu deneme modeline göre yarı deneysel olarak gerçekleştirilen araştırmanın kapsamına, bir üniversitede hemşirelik birinci sınıf öğrencisi olup, Bilgiye Ulaşma ve Kullanma Modülü "Sağlığı Geliştirme" dersine katılan ve araştırmaya katılmayı kabul eden öğrenciler alınmıştır ( $n=126)$.

Yansız atama yöntemi ile okul numaraları tek olan öğrenciler deney ve çift olan öğrenciler ise kontrol grubunu oluşturacak şekilde belirlenmiştir. Deney grubu; alt şapkalı düşünme tekniğine göre hazırlanmış dersin uygulandığı ve sınıf ortamının bu plana göre düzenlenip öğrenimin yapıldığı gruptur. Kontrol grubu ise; dersin geleneksel çalışmalarla (düz anlatım, soru-cevap vs.) işlendiği gruptur.

Araştırma verileri, araştırma için kurumdan gerekli yazılı izin ve öğrencilerden sözlü onam alınarak, 10-15 Nisan 2011 tarihlerinde, çalışmanın başında ve sonunda verilen "Tanıtıcı Bilgi Formu" ve araştırmacılar tarafindan ilgili literatür doğrultusunda ön-test, son-test olarak hazırlanan "Sağlığı Geliştirme" dersine ilişkin çoktan seçmeli ve açık uçlu 15 sorudan oluşan başarı testi kullanılarak toplanmıştr. Ayrıca deney grubundaki öğrencilerden altı şapkalı düşünme tekniğine ilişkin geri bildirim almak amacıyla 20 sorudan oluşan yapılandırılmış bir soru formu kullanılmıştır.

Araştırmanın gereği her iki grup için farklı ortam oluşturulmuştur. Buna göre deneysel çalışmanın yapılacağı ortam şu şekilde düzenlenmiştir. Çalışmanın başında her konu için alt şapkalı düşünme tekniğine dayalı senaryo ve sorular hazırlanmış ve verilebilecek muhtemel cevaplara göre öğrencilerin düşünüşleri bu sorulara yoğunlaştrılmaya çalışılmıştr. Deney grubunu oluşturan sınıfin öğrencilerine takılacak şapkalar öğrenciler tarafindan hazırlanmış, renkleri ve rolleri hakkında kapsamlı açıklamalar yapılmıştır. Dersin işlenişi sırasında sorular değiştikçe öğrencilerin dersi daha zevkli işlenmesi için alt farklı renkte hazırlanan şapkalar öğrenciler tarafindan takılarak çok yönlü düşünmelerine imkan sağlanmıştır. Kontrol grubunu oluşturan sınıflarda "Sağlığı geliştirme" dersi geleneksel yöntem kabul edilen düz anlatım ve soru-cevap tekniği kullanılarak gerçekleştirilmiştir. 
Verilerin analizinde, sosyodemografik veriler ve Alt Şapkalı Düşünme tekniğinin uygulanmasına ilişkin deney grubu öğrencilerinin görüşlerini değerlendirebilme için SPSS paket programı kullanılarak, sayı, yüzdelikleri alınmış, gruplar arası ön test son test karşılaştırmalarını değerlendirebilmek için t-testi analizleri yapılmıştır.

\section{Bulgular}

Çalışmaya katılan (n:126) birinci sınıf hemşirelik öğrencilerinin \%65,1'inin 18-20, \%30,16'sının 21-22, \%4,76'sının 23 ve üstü yaş grubunda ve \%18,25'inin erkek, \%81,7'sinin kız öğrenci olduğu belirlenmiştir (Grafik 1).

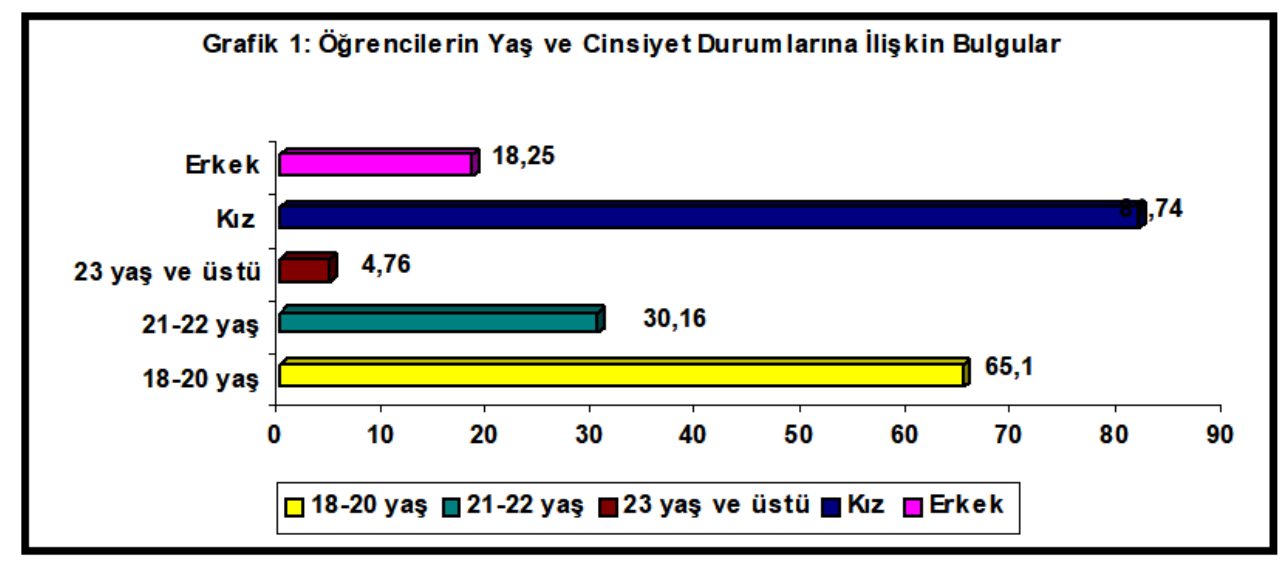

\section{Grafik 1. Öğrencilerin Yaş ve Cinsiyet Durumlarına İlişkin Bulgular}

\section{Birinci Alt Probleme ilişkin Bulguların Dağılımı}

Araştırmanın birinci alt problemi "Alt şapkalı düşünme tekniğine göre hazırlanan bir dersin uygulandığı eğitim ortamı ile klasik yöntemle hazırlanan bir dersin uygulandığı eğitim ortamının öğrenme başarısına etkisi nasıldır?" şeklinde ifade edilmiştir ve bulgular Tablo 1'de gösterilmiştir.

Tablo 1. Deney ve Kontrol Grubu Ön test-Son test Sonuçlarına ilişkin Bulgular

\begin{tabular}{|c|c|c|c|c|c|c|}
\hline & & $\mathrm{n}$ & $\mathrm{X}$ & SD & $\mathrm{t}$ & $\mathrm{p}$ \\
\hline \multirow{2}{*}{ Deney } & Ön test & 63 & 25,25 & 6,68 & \multirow{2}{*}{$-16,037$} & \multirow{2}{*}{, $00 *$} \\
\hline & Son test & 63 & 58,09 & 18,09 & & \\
\hline \multirow{2}{*}{ Kontrol } & Ön test & 63 & 25,36 & 7,74 & \multirow{2}{*}{$-16,253$} & \multirow{2}{*}{, $00 *$} \\
\hline & Son test & 63 & 51,98 & 14,32 & & \\
\hline Deney & Son test & 63 & 58,09 & 18,09 & \multirow{2}{*}{2,102} & \multirow{2}{*}{,038* } \\
\hline Kontrol & Son test & 63 & 51,98 & 14,32 & & \\
\hline Deney & Ön test-son test puan farkı & 63 & 32,84 & 16,25 & \multirow{2}{*}{2,373} & \multirow{2}{*}{,019* } \\
\hline Kontrol & Ön test-son test puan farkı & 63 & 26,61 & 12,99 & & \\
\hline
\end{tabular}

Deney ve kontrol grubunun ön testleri arasında yapılan $t$ testi analizi sonucunda istatistiksel olarak anlamlı bir fark bulunmamıştı (t:-.086, p>0.05). Ön test sonuçları incelendiğinde grupların homojen oldukları söylenebilir. Deney grubunun ön testi $(25,25 \pm 6,68)$ ile alt şapkalı düşünme tekniği ile işlenen ders sonrasında uygulanan son testin $(58,09 \pm$ 18,09) puan ortalamaları arasında yapılan $t$ testi sonucunda istatistiksel olarak anlamlı bir fark olduğu belirlenmiştir $(p<0.05)$ (Tablo 1). Beklenenin aksine, kontrol grubunun ön testi $(25,36 \pm 7,74)$ ile geleneksel yöntem ile işlenen ders sonrasında uygulanan son testin $(51,98 \pm 14,32)$ puan ortalamaları arasında da yapılan $t$ testi sonucunda istatistiksel olarak anlamlı bir fark bulunmuştur ( $p<0.05$ ) (Tablo 1 ). Deney ve kontrol grubu öğrencilerinin ön test-son test puan farklarının karşılaştrılması için yapılan t testi sonucunda istatistiksel olarak anlamlı bir fark bulunmuştur $(p<0.05)$ (Tablo 1).

Deney ve kontrol grubunun son test puan ortalamaları karşılaştırıldığında ise, deney grubunun son test puan ortalaması $(58,09 \pm 18,09)$ ile kontrol grubunun son test puan ortalaması $(51,98 \pm 14,32)$ arasında yapılan $t$ testi sonucunda istatistiksel olarak anlamlı bir fark olduğu belirlenmiştir $(p<0.05)$ (Tablo 1 ).

\section{íkinci Alt Probleme iliş̧kin Bulguların Dağılımı}

Deney grubu öğrencilerinin alt şapkalı düşünme tekniğine yönelik olumlu ve olumsuz düşüncelerini belirlemek için 
verilen 20 sorunun dağııımı Tablo 2'de verilmiştir.

Öğrencilerin en yüksek oranda katıldıkları cümleler; "Konuyu farklı yönleriyle düşünmeyi öğrendim (\%92,1)", "Yaratıcılığımın gelişmesine katkı sağladı $(93,7)$ ", "Vakanın olumlu ve olumsuz yönlerini farketmemi sağladı (\%93,7)", "Farkıı fikir ve düşüncelerin paylaşılmasını sağladı $(\% 93,7)$ ", "Ezberden uzaklaştırarak, edindiğim bilginin kalıcılığını sağladı $(\% 93,7)$ " olmuştur. Öğrencilerin en düşük oranda katıldıkları cümle ise; "Empati sempatiye dönüştü ve beni kötü etkiledi $(\% 12,7)$ ", "Özellikle siyah şapka etkinliği (olumsuz) beni karamsar yapt $(22,2)$ ” cümleleri olmuştur.

Tablo 2. Alt Şapkalı Düşünme Tekniğinin Uygulanmasına İlişkin Deney Grubu Öğrencilerinin Görüşlerinin Dağılımı

\begin{tabular}{|c|c|c|c|c|c|c|}
\hline \multirow{2}{*}{ Öğrenci Görüşleri } & \multicolumn{2}{|c|}{ Katilıyorum } & \multicolumn{2}{|c|}{ Kararsızım } & \multicolumn{2}{|c|}{ Katilmıyorum } \\
\hline & Sayı & $\%$ & Sayı & $\%$ & Sayı & $\%$ \\
\hline Yaratıcı fikirler üretmemi sağladı & 56 & 88,9 & 4 & 6,3 & 3 & 4,8 \\
\hline Bireye/hastaya empati yapmamı kolaylaştırdı & 58 & 92,1 & 2 & 3,2 & 3 & 4,8 \\
\hline Empati sempatiye dönüştü, beni olumsuz etkiledi & 8 & 12,7 & 13 & 20,6 & 42 & 66,7 \\
\hline Dersi daha iyi anlamamı sağladı & 55 & 87,3 & 5 & 7,9 & 3 & 4,8 \\
\hline Farklı fikir ve düşüncelerin paylaşılmasını sağladı & 59 & 93,7 & 1 & 1,6 & 3 & 4,8 \\
\hline Bireyi/hastayı holistik (bütüncül) ele almamı sağladı & 55 & 87,3 & 6 & 9,5 & 2 & 3,2 \\
\hline Özellikle siyah şapka etkinliği (olumsuz) beni karamsar yapt & 14 & 22,2 & 11 & 1,5 & 38 & 60,3 \\
\hline Vakanın olumlu ve olumsuz yönlerini farketmemi sağladı & 59 & 85,7 & 7 & 11,1 & 2 & 3,2 \\
\hline Kaliteli sağlık eğitimi vermemi destekleyecek & 54 & 85,7 & 7 & 11,1 & 2 & 3,2 \\
\hline Duygularımın farkına varmamı, kendimi tanımamı sağladı & 41 & 65,1 & 16 & 25,4 & 6 & 9,5 \\
\hline Düşünce sistemlerimi geliştirdi & 51 & 81 & 8 & 12,7 & 4 & 6,3 \\
\hline Konuyu farklı yönleriyle düşünmeyi öğrendim & 58 & 92,1 & 3 & 4,8 & 2 & 3,2 \\
\hline Farklı düşüncelere saygı duymamı sağladı & 56 & 88,9 & 5 & 7,9 & 2 & 3,2 \\
\hline Eski bilgilerimi kullanmamı sağladı & 54 & 85,7 & 7 & 11,1 & 2 & 3,2 \\
\hline Yaratıcılığım gelişmesine katkı sağladı & 59 & 93,7 & 2 & 3,2 & 2 & 3,2 \\
\hline Konuyu altı farklı boyutta tartışmak zaman alıyor & 33 & 52,4 & 9 & 14,3 & 21 & 33,3 \\
\hline Derse olan ilgi ve motivasyonumu arttırdı & 55 & 87,3 & 6 & 9,5 & 2 & 3,2 \\
\hline Eleştirel düşünmemi sağladı & 54 & 85,7 & 7 & 11,1 & 2 & 3,2 \\
\hline Edindiğim bilgilerin analiz ve sentezini sağladı & 53 & 84,1 & 7 & 11,1 & 3 & 4,8 \\
\hline Ezberden uzaklaştırarak, edindiğim bilginin kalıcılığını sağladı & 59 & 93,7 & 1 & 1,6 & 3 & 4,8 \\
\hline
\end{tabular}

\section{Üçüncü Alt Probleme İlişkin Bulguların Dağılımı}

“Altı Şapkalı Düşünme tekniğinin uygulanması sırasında öğrenciler tarafindan geliştirilen kavramlar nelerdir?"şeklinde ifade edilmiştir. Öğrenciler tarafindan oluşturulan bu kavramlar verilen senaryo doğrultusunda her bir şapkada öğrencilere yöneltilen sorular doğrultusunda elde edilmiştir. Öğrencilere verilen senaryo ve her bir şapkada sorulan sorular ve üretilen kavramlar Şekil 1, Tablo 3 ve Tablo 4'te verilmiştir.

Senaryo : İnci 16 yaşındaydı. Hayatının en önemli sınavına hazırlanıyordu. Günleri çok yoğun ve uykusuz geçiyordu. Sınav bitince rahatlayacağım diyordu. Bu yoğun tempo içerisinde yemek düzeni değişmiş, daha çok fast-food yiyeceklere yönelmiş, okul ile dershane arasında yaşamını geçirmekten yiyeceklerine dikkat edememeye başlamıştı. Üniversite hayallerinin yanında kazanamama korkusunu yaşayıp, stresli hissediyordu kendisini. Böyle anlarda tatlı krizine girip çikolataya saldırıyordu. Gün geçtikçe çok sevdiği kıyafetleri üstüne olmamaya başladı, yüzünde ergenliğin getirmiş olduğu sivilcelerle birlikte yanakları da şişmeye başlamıştı. Artık kendini beğenmiyor, arkadaşlarının onunla dalga geçtiğini düșünüyordu. Bir erkek arkadaşı da yoktu, hiçbir zaman olamayacağını düșünmeye başlamıștı. Her sabah tartılıyordu fakat kilo alımı da devam ediyordu. Sınava hazırlanmaktan ne spor yapmaya zamanı vardı ne de bir sosyal hayatı. Kendisini ayna da gördükçe görüştüğü arkadaşlarıyla da görüșmemeye bașlamıștı. Okul hemşiresi, İncinin durgunluğundan, teneffüslerde arkadaş gruplarına katılmadığını fark ederek İnciyi odasına çağırdı

Şekil 1. Alth Şapka Düşünme Tekniğinde Kullanılan Senaryo

| Kastamonu Eğitim Dergisi, 27(4), 2019| 
Tablo 3. Alt Şapka Düşünme Tekniğinde Kullanılan Sorular

Beyaz Şapka Soruları K Kırmızı Şapka Soruları Şapa Soruları

Sizce İnci durumu hakkında ne düşünüyor İnci'nin yerinde olsaydınız ne hissederdi- Sağlıksız bir yaşama sahip olmanın dezave kendisinin farkında mı? niz?

vantajları nelerdir?

İnci'nin geleceğe ait endişeleri ve ümitleri İnci'nin sağlık durumu ile ilgili olumlu de- İnci sağlığı kötüleşip hastalanabilir mi? nelerdir?

ğişiklikler olmazsa bu durumda İnci ne hisseder?

Inci'nin beslenme sorununun sağlığı üzerindeki olumsuz etkileri nelerdir?

İnci'nin ailesi sağlık durumu hakkında ne İnci'nin üniversite sınavı öncesi yaşamış hissediyordur? olduğu bu stresli durum İnci'yi nasıl etkiler

İnci'nin arkadaşları İnci'nin bu duygularından haberdar mıdır? Haberdar olsalar ne hissederdiler?

Inci'nin yerinde olup tekrardan eski sağıı̆ınıza kavuşsaydınız ve sağlıklı yaşam davranışlarını yeniden kazansaydınız ne düşünürdünüz?

Sarı Şapka Soruları

Yeşil Şapka Soruları

Mavi Şapka Soruları

Sağlıklı yaşam davranışlarına sahip bireyin yaşadığı konfor nedir?

İnci için bir sağlık eğitimi hemşiresi olarak

Inci'nin sağlığını geri kazanması hakkında İnci'ye ve ailesine sağlıklı yaşam davranışları eğitimi verme konusundaki görüşlerikazandıracağınız davranışlar ne olurdu ve ne düşünüyorsunuz? hangi konularda eğitim verirdiniz? niz nelerdir?

Inci'nin destek sistemleri nelerdir?

İnci'nin bundan sonra neler yapması gerekiyor?

Ailesi dışında İnci'ye destek olabilecek ki- Biz bundan sonra ne yapmalıyız? şiler kimlerdir? Bunları keşfetmesi için ne- Şu ana kadar neler başardık? ler yapılabilir?

İnci'nin bu durumundan kurtulması için hangi çözüm önerilerini sunardınız?

Daha fazlasını başarmak için neler yapmalıyız?

Tablo 4. Alț Şapka Düşünme Tekniği Sonucu Ortaya Çıkan Kavramlar

\begin{tabular}{|c|c|c|}
\hline Beyaz şapka Kavramlar & Kırmızı Şapka Kavramlar & Siyah Şapka Kavramalar \\
\hline Asosyallik & Ağlama & Obezite \\
\hline Aşırı kilo & Çaresizlik & İlaç tüketimi \\
\hline Başarısızlık & Karamsarlık & Asosyallik \\
\hline Endişe & Yalnızlık & Depresyon \\
\hline Yalnızlık & Değersizlik & HT \\
\hline \multirow[t]{13}{*}{ Beğenilmeme } & Umutsuzluk & DM \\
\hline & Kızgınlık & Kalp hastalıkları \\
\hline & İsyan & Diyare \\
\hline & Ders çıkarma & Panik atak \\
\hline & Kendine güvenme & Gastrit \\
\hline & Dışlanma & Blumiya \\
\hline & Benlik saygısı & Verem \\
\hline & Madde kullanımı & CA \\
\hline & Utanma & Uyku bozuklukları \\
\hline & Sinirlilik & Güven kaybı \\
\hline & Umut & \\
\hline & Hırs & \\
\hline & Kıskançlık deneyim kazanma & \\
\hline Sarı Şapka Kavramlar & Yeşil Şapka Kavramlar & Mavi Şapka Kavramlar \\
\hline Neşeli olma & Beslenme & Umut \\
\hline Kendinin farkına varma & Stres yönetimi & Pozitif düşünme \\
\hline Güven & Cilt hijyeni & Destek \\
\hline İyi iletişim & Sosyalleşme & Geribildirim \\
\hline Motivasyon & Egzersiz & Özgüven \\
\hline Sosyal destek & Uzman yardımı & \\
\hline \multirow[t]{2}{*}{ Kendine inanma } & Motivasyon & \\
\hline & Sosyal destek & \\
\hline
\end{tabular}




\section{Tartışma}

Bu çalışmada, "Alt şapkalı düşünme tekniğine göre hazırlanan bir dersin uygulandığı eğitim ortamı ile klasik yöntemle hazırlanan bir dersin uygulandığı eğitim ortamının öğrenme başarısına etkisi nasıldır?", Deney grubu öğrencilerinin alt şapkalı düşünme tekniğine yönelik olumlu ve olumsuz düşünceleri nelerdir? ve "Altı Şapkalı Düşünme tekniğinin uygulanması sırasında öğrenciler tarafindan geliştirilen kavramlar nelerdir? sorularına yanıt aranmıştır.

Deney ve kontrol grubunun ön test ile son test puan ortalamaları arasında yapılan $t$ testi sonucunda istatiksel olarak anlamlı bir fark olduğu belirlenmiştir (Tablo 1). Karadağ ve ark. (2015)'larının hemşirelik öğrencileri üzerinde yaptıkları çalışmalarında da alt şapka tekniğiyle eğitim alan grubun ön test ve son test puan ortalamaları arasında arţ̧ıın olduğu ve istatistiksel olarak anlamlı bir farkın bulunduğu ifade edilirken geleneksel anlatım yönteminin uygulandığı grubunda puan ortalamaları arasında anlamlı farkın bulunduğu belirtilmiştir. Öğretmen merkezli öğretim yaklaşımı olan geleneksel anlatma yöntemiyle ve öğrenci merkezli yaklaşım olan altı şapka düşünme tekniğiyle yürütülen sağlığı geliştirme dersi sonucunda öğrencilerin bilgi düzeylerinde her iki yöntem ve tekniğin etkili olduğu görülmektedir.

Althkulaç ve Akhan (2010)'ın ilköğretim 8. sınıf öğrencileri üzerinde yaratıcı drama yöntemi ve alt şapkalı düşünme tekniği kullanarak yaptıkları çalışmalarında da alt şapkalı düşünme tekniği kullanılan deney ve kontrol grubu öğrencilerinin son test puan ortalamasının ön test puan ortalamasından daha yüksek olduğu ve ön test-son test puan ortalamaları arasında istatistiksel olarak anlamlı bir farkın bulunduğu ifade edilmektedir. Diğer bir çalışmada da deney ve kontrol grubundaki öğrencilerin ön test-son test puan ortalamaları arasında bir artı̧ın olduğu saptanmış olup bu artışın istatistiksel olarak anlamlı olduğu ifade edilmiştir (Kaya, 2013). Çalışmamızda da kontrol grubuna geleneksel yöntem uygulanarak ders işlenmesine rağmen ön test-son test puan ortalamaları arasında artı̧̧ olduğu bulunmuş olup istatistiksel olarak anlamlı bir fark saptanmıştır. Bu yöntem sonucunda da öğrenci başarısında bir artı̧̧ olduğunu göstermektedir. Bu çalışmalar doğrultusunda çalışma bulgumuz literatür ile paralellik göstermektedir. Altı şapkalı düşünme tekniğinin öğrencilerin bilgi düzeylerine olumlu katkı sağladığı söylenebilir.

Her iki grupta farklı yöntem ve teknikler ile dersin işlenmesi sonucunda son test puan ortalamalarında artış saptanmış olsa da deney ve kontrol grubunun son test puan ortalamaları arasında yapılan $t$ testi sonucunda istatiksel olarak anlamlı bir fark olduğu belirlenmiştir (Tablo 1). Ortalamalara bakıldığında; deney grubunun son testten aldıkları puanların kontrol grubundan yüksek olması, geleneksel yöntemin öğrencilerin başarı düzeylerini arttrrmada yetersiz kaldığını düşündürmekte olup, deneysel çalışmada kullanılan alt şapkalı düşünme tekniğinin başarıyı geleneksel yönteme göre daha çok arttırdığı yönünde söylenebilir. Nitekim, Can (2005) tarafindan yapılan çalışmada da geleneksel yöntemin öğrencilerin başarı düzeylerini arttırmada yetersiz kaldığı bulunmuştur. Bu çalışma, yapılan çalışma bulguları ile paralellik göstermektedir. Diğer bir çalışma olan Özen ve arkadaşları (2008)'nın ilköğretim beşinci sınıf öğrencileri üzerinde yaptkkları çalışmalarında altı şapkalı düşünme tekniğinin öğrencilerin test sorularına doğru cevap verme oranında artş̧ sağladığı ve sınavlardaki ortalama başarının çok yüksek düzeyde olduğu ifade edilmiştir. Orhan ve arkadaşları (2012)'nın öğrencilerin konuşma becerisini geliştirmeye yönelik yapmış oldukları çalışmalarında da uygulama öncesi deney ve kontrol grupları başarı seviyesi bakımından yakın değerlerde bir ortalamaya sahipken deney grubu araştırma süreci sonunda kontrol grubuna göre olumlu yönde anlamlı bir farkın olduğu saptanmıştır.

Kırmızı (2012)'nın lise öğrencileri üzerinde yapmış olduğu çalışmasında deney grubunun son test puan ortalamasının kontrol grubuna göre daha yüksek olduğu ve istatistiksel olarak anlamlı bir fark bulunduğu ifade edilmektedir. Altı şapkalı düşünme tekniği uygulanan literatürdeki çalışmalar incelendiğinde alt şapkalı düşünme tekniği uygulanan deney gruplarının son test puan ortalamalarının kontrol grubundan daha yüksek ve istatistiksel olarak anlamlı bir farkın olduğu ifade edilmektedir (Can ve Semerci, 2007; Alttkulaç ve Akhan, 2010; Epçaçan ve arkadaşları, 2012; Güneş ve Demir, 2013). Bu Farklılı̆ın deney grubunda kullanılan Alt Şapkalı Düşünme Tekniği'nin başarıyı geleneksel yöntemlere göre daha çok arttırdığı ve diğer geleneksel tekniklerden daha etkili bulunduğu savunulmaktadır.

Güneş ve Demir (2013)'in çalışmasında deney ve kontrol grubunun son test puan ortalamaları arasında, deney grubu lehine 23.04 puanlık bir fark olduğu ifade edilmektedir. Bu fark, deney grubu öğrencilerine alt şapkalı düşünme tekniğinin uygulamasının kontrol gurubu öğrencilerine göre akademik başarıyı anlamlı bir düzeyde artırdığını saptamışlardır. Çalışmamızda da deney grubunun son test puan ortalamasının kontrol grubuna göre daha yüksek olduğu görülmektedir (Tablo 1).

Yaratıcı düşünme teknikleri ile yapılan önceki çalışmalarda da benzer sonuçlar ile karşılaşılmaktadır. Mitez (2012), alt şapkalı düşünme tekniğinin kullanımının, öğrencileri birbirine bağlayarak güçlendirdiğini ve düşünmeyi sınıflandırarak zamanı koruduğunu belirtmektedir. Seymour ve arkadaş (2003)'larının çalışması da yaratıcı düşünme teknikleri ile düşünce çeşitliliğine teşvik ettiğini ve değişime intiyaç olan alanlarda kullanılabileceğini desteklemektedir. Gonzalez 
(2001) inovasyon ve yaratıcılığı geliştirdiği, işbirlikçi düşünmeye zorladığını, basit bir dil sağlayarak çalışmayı kolaylaştırdığını vurgulamaktadır. Taei ve Kamel (2013) yaratıcı düşünme tekniklerinin karar alınırken egonun kalkmasına yardımcı olduğunu egoyu korkutmadan düşüncelerde değişikliğe izin verdiğini belirtmektedirler. Yaratıcı düşünme araştrma, eğitim, yönetim, uygulama alanları gibi hemşireliğin birçok farklı alanı için en gerekli becerilerden bir tanesi olduğu kanıtlanmıştır (Chan, 2013). Bu literatür doğrultusunda yaratıcı düşünmeyi sağlayan alt şapkalı düşünme tekniğinin eğitim ortamında öğrencilere çekinmeden yanlış bir şey söylüyorum korkusu yaşatmadan güven ortamını sağlamakta olduğu, öğrencilerin derse katııımını artırarak düşüncelerinin sınıflandırılmasıyla zaman kaybı olmadan etkin bir ders ortamının yaratılabileceği düşünülmektedir. Alt şapkalı düşünme tekniğinin öğrenci başarı düzeyinde de olumlu yönde etkili olabileceği söylenebilinir.

Deney grubu öğrencilerinin alt şapkalı düşünme tekniğine yönelik olumlu ve olumsuz düşüncelerini belirlemek için verilen 20 sorunun dağılımı tablo 4'de verilmiştir. Öğrencilerin en yüksek oranda katıldıkları cümleler; "Konuyu farklı yönleriyle düşünmeyi öğrendim $(\% 92,1)$ ", "Yaratıcılığımın gelişmesine katkı sağladı $(93,7)$ ", "Vakanın olumlu ve olumsuz yönlerini farketmemi sağladı (\%93,7)", "Farklı fikir ve düşüncelerin paylaşılmasını sağladı (\%93,7)", "Ezberden uzaklaştırarak, edindiğim bilginin kalıcılığını sağladı $(\% 93,7)$ " olmuştur. Öğrencilerin en düşük oranda katıldıkları cümle ise; "Empati sempatiye dönüştü ve beni kötü etkiledi $(\% 12,7)$ ", "Özellikle siyah şapka etkinliği (olumsuz) beni karamsar yapt $(22,2)$ " cümleleri olmuştur. Öğrencilerin çoğunluğu altı şapkalı düşünme tekniğine ilişkin olumlu yönde görüş bildirmişlerdir. Öğrenciler, tekniğin farklı, eğlenceli, zevkli olduğunu ifade etmişler ve fikirlerini çekinmeden açıklayabildiklerini, farklı fikirler aracılı̆ı ile yeni şeyler öğrenebildiklerini ortaya koymuşlardır. Bu bulgu Koray (2005) tarafindan yapılan çalışma bulguları ile benzerlik göstermekte olup, çalışma bulgularını destekler niteliktedir.

Diğer bir çalışmada da alt şapka düşünme tekniğiyle yapılan öğretim etkinliklerine yönelik; dersin eğlenceli geçtiği, derse daha fazla katılımın sağlandığı ve olayların farklı yönleriyle değerlendirildiği, işbirliği içinde daha fazla öğrenmenin gerçekleştiği şeklinde olumlu görüş bildirdiklerini ifade etmektedir. Bunların yanı sıra yapılan öğretim etkinliklerinin yorucu ve sıkıcı geçtiğine yönelik olumsuz görüş de bildirilmiştir (Kaya, 2013). Özen ve arkadaşları (2008)'nın ilköğretim beşinci sınıf öğrencileri üzerinde yaptıkları çalışmalarında altı şapkalı tekniği ile işlenen dersin öğrencilerin derse katIımlarını arttırdığını ve ezbercilik yerine, anlamlı ve kalıcı öğrenmeye katkı sağladığını belirtmişlerdir. Can ve Semerci (2007)'nin yapmış oldukları çalışmalarında, dersi iyi öğrenmelerini sağladığını, bir olaya sadece olumlu değil de olumsuz olarak da bakabildiklerini, herkesin yeni fikir ürettiği ve fikrini açığa koyabildiklerini gibi altı şapkalı düşünme tekniği ile ilgili görüşlerini bildirmişlerdir.

Hemşirelik öğrencileri üzerinde yapılan çalışmalardan biri olan Karadağ ve arkadaş (2006)'larının çalışmalarında \%75.6'sı "Yaratıcı Fikirler Üretmeme Yardımcı Oldu”, \%85.4'ü “Hastalara Empati Kurmamı Kolaylaştrdı”, \%85.3'ü “Hastayı Holistik Ele Almamı Sağladı”, \%82,9'u “Hastalıkların Olumlu Ve Olumsuz Yönlerini Fark Etmemi Sağladı", \%90,2'si "Konunun Farklı Yönlerinin Düşünmeyi Öğretti”, \%24,4’ü “Konutu Alt Farklı Boyutta Tartşsmak Zaman Kaybı”, \%26,8'i "Özellikle Siyah Şapka Etkinliği (Olumsuz) Beni Karamsar Yapt", \%12,2'si “Empati Sempatiye Dönüştü, Beni Olumsuz Etkiledi" görüşüne katıldıkları saptandığı belirtilmiştir. Taie ve Kamel (2013)'in çalışmalarında ise öğrenci görüşlerinin, \%88'i “Yaratııı Fikirler Üretmeme Yardımcı Olduğunu”, \%92'si "Bireye/Hastaya Empati Yapmamı Kolaylaştrdığını", \%96'sı “Odaklanmama Yardımcı Olduğunu”, \%94'ü “Farklı Düşünce Ve Fikirleri Paylaşmamı Sağladığı” görüşüne katlırken, \% 90’। “Empati Sempatiye Dönüştü", "Beni Olumsuz Etkiledi” ve \% 86'sı "Özellikle Siyah Şapka Etkinliği (Olumsuz) Beni Karamsar Yapt" görüşüne katılmadığını saptamışlardır. Literatürde altı şapkalı düşünme tekniği ile ilgili çalışmalarda saptanan görüşler, çalışmamızın bulgularını destekler niteliktedir.

Çalışmamızda senaryo doğrultusunda şapkalara sorulan sorular sonrasında ortaya çıkan kavramlar, öğrencilerin sağlık eğitimi vermeden önce düşünmeleri gereken farklı boyutları ortaya çıkararak öğrencilerin sağlık eğitimi verme yaklaşımlarını etkileyeceğini ortaya çıkarmıştr. Karadağ ve Erginer (2008)'in öğrenci hemşireler üzerinde meme kanseri konusu üzerine alt şapkalı düşünme tekniği ile yürüttükleri çalışmalarında her bir şapkanın kimliğine özgü kavramlar bulunmuştur. Çalışmamızın ve bu çalışmanın konu alanları farklı olmasına rağmen şapkalara özgü olumlu, olumsuz, yaratıcılıkla vb. ilişkili kavramlar ortaya çıktı̆ı görülmektedir.

\section{Sonuçlar}

Çalışma sonucunda alt şapkalı düşünme tekniği uygulanan grubun son test puan ortalamalarının daha yüksek olduğu bulunmuştur. Yüksek öğretimde Alt Düşünme Şapkası etkinliğinin öğretim tekniği olarak sınırlı sayıda çalışmada kullanıldığı saptanmıştır. Hemşirelik eğitiminde de sınırlı sayıda literatür bilgisine ulaşılması nedeniyle, hemşirelik literatüründe bu tür çalışmaların yer almasının hemşirelik eğitiminin gelişmesi ve eğitim yöntemlerinin zenginliği açısından önemli olduğu kanısına varılmıştır. Öğrencilerin öğrenmelerini geliştirmesinin yanı sıra bir olaya farklı çerçevelerden bakabilmesini, kendi duygularının farkına varabilmesini ve eleştirel düşünme becerilerini geliştirmesi, hastaya bütüncül 
bir bakım sağlayabilmesi açısından alt şapkalı düşünme tekniğinin hemşirelik eğitiminde kullanılması önemlidir.

\section{6. Öneriler}

Bu çalışmanın hemşirelik öğrencilerinin kritik düşünme yeteneklerinin gelişmesi için önemli olan yaratıcı eğitim yönteminin kullanımının test edilmesi açısından önemli olduğu düşünülmektedir. Yaratıcılık her bireyde eğitimle kazandırılabilecek bir özelliktir. Bu nedenle; eğitim programlarından, öğretim yöntem ve tekniklerine kadar eğitim sisteminin her aşamasında işlenmesi, kullanılması; toplumları, gelecekte refah seviyesine çıkarabilecek nitelikli bireylerin yetişmesine katkıda bulunacaktır. Ayrıca, bu alan ile ilgili yapılacak çalışmaların arttırılması ile araştırmanın genellenebilirliği açısından daha etkili olabileceği önerilmektedir.

\section{Kaynakça}

Altıkulaç, A., \& Akhan, E. N. (2010). 8. Sınıf İnkılâp Tarihi ve Atatürkçülük Dersinde Yaratıcı Drama Yöntemi ve Altı Şapkalı Düşünme Tekniğinin Kullanıımasının Öğrenci Başarı ve Tutumlarına Etkisi, Ahi Evran Üniversitesi Eğitim Fakültesi Dergisi, 11(3): $225-247$.

Aybek, B., (2007). Eleştirel düşünmenin öğretiminde Öğretmenin rolü (Teacher's role in critical thinking education). Bilim Eğitim ve Düşünme Dergisi, 7(2):88-98.

Berber, F., Akbulut, F., Maden, H., Gezer, M., \& Keser, Ş. (2002). Düşünme ve Eleştirel Düşünme. Özel Öğretim Yöntemleri Dersi Araştırma Projesi Raporu. Süleyman Demirel Üniversitesi, Teknik Eğitim Fakültesi.

Büyükdokumacı, H., \& Baştürk, R. (2010). Altı şapkalı düşünme tekniğinin 6. Sınıf fen ve teknoloji eğitimi solunum konusunda öğrenci başarısı üzerinde etkisi, 9. Ulusal Sınıf Öğretmenliği Eğitimi Sempozyumu (20- 22 Mayıs 2010), Elazığ, 303-306

Can, A. H., \& Semerci, N. (2007). Alt Şapkalı Düşünme Tekniğinin IIlköğretim Sosyal Bilgiler Dersinde Öğrencilerin Akademik Başarısına Etkisi, Eğitim ve Bilim, 32(145):39-52.

Chan, C.Y.Z. (2013). A Systematic Review Of Creative Thinking/Creativity In Nursing Education. Nurse Education Today, 33:1382-1387.

Daly, W. (1998). Critical thinking as an outcome of nursing education. What is it? Why is it important to nursing practice? Journal of Advanced Nursing, 28(2):323-331.

De Bono, E. (2006). Alt Şapkalı Düşünme Tekniği, İstanbul: Remzi Kitabevi.

Epçaçan, C., Ulaş, H., Orhan, S., Epçaçan, C., \& Gedík, M. (2012). Alt Şapka Düşünme Tekniğinin İlköğretim Altıncı Sınıf Öğrencilerinin Yazma Becerilerini Geliştirmeye Etkisi. Akademik Araştirmalar Dergisi, 55:105-120.

Erginer, E., 2000. Öğretimi Planlama Uygulama ve Değerlendirme. Ankara: Anı Yayıncılık

Goebel, G., \& Seabert, D. (2006). Put on your thinking hats. Journal of School Health, 76(4):393-395

Gonzalez, D. (2001).The Art of Solving Problems: Comparing the Similarities and Differences Between Creative Problem Solving, Lateral Thinking and Synectics. New York: International Center for Studies in Creativity, 1-96.

Güneş, H. M., \& Demir, S. (2013). Endokrin Sistem Konusunun Altı Şapkalı Düşünme Tekniğiyle Anlatılmasının Öğrenci Başarısı Üzerine Etkisi. Türk Fen Eğitimi Dergisi, Haziran, 10(2):101-115.

Karadağ, M., Sarıtaş, S., \& Erginer, E. (2006). Using The "Six Thinking Hats"Model Of Learning İn A Surgical Nursing Class: Sharing Experience And Student Opinions. Australian Journal of Advanced Nursing, 26(3): 59-69.

Karadağ, M., \& Erginer, E. (2008). Hemşirelik Eğitiminde Altı Düşünme Şapkası Etkinliğinin Kullanılması. Hemşirelikte Araştırma Geliştirme Dergisi.3(10):30-44.

Kaya, F. M. (2013). Siirt Üniversitesi Coğrafya Derslerinde Sürdürülebilir Kalkınmaya Yönelik Konuların Öğretiminde Alt Şapkalı Düşünme Tekniğinin Öğrenci Başarısına Etkisi, Kuram ve Uygulamada Eğitim Bilimleri, Bahar, 13(2):1125-1139.

Koray, Ö. (2005). Altı Düşünme Şapkası ve Nitelik Sıralama Tekniklerinin Fen Derslerinde Uygulanmasına Yönelik Öğrenci Görüşleri. Kuram ve Uygulamada Eğitim Yönetim, Yaz, (43): 379-400.

Kırmızı, B. (2012). Almanca Derslerinde Alt Şapkalı Drama Tekniğinin Öğrencilerin Başarısına Etkisi, Adıyaman Üniversitesi Sosyal Bilimler Enstitüsü Dergisi, ISSN: 1308-9196, 5: 265-290.

Mitez, S. (2012). Six Thinking Hats. Asian Journal of Management Research, 2(2): 814-820.

Orhan, S., Kırbaş, A., Topal, Y. (2012). Görsellerle Desteklenmiş Alt Şapka Düşünme Tekniğinin Öğrencilerin Konuşma Becerilerini Geliştirmesine Etkisi. International Periodical For the Languages, Literature and History of Turkish or Turkic, 7(3): 1893-1909.

Özen, Y.,Gül, A., \& Gülaçt, F. (2008). İlköğretim Beşinci Sınıflar Sosyal Bilgiler Dersi “Cumhuriyete Nasıl Kavuştuk” Ünitesindeki “Atatürk illkeleri Ve İnkılâpları”Adlı Konunun Alt Köşeli Şapka Drama Tekniği Ille Uygulanmasının Öğrenci Başarısına Etkisi. Erzincan Eğitim Fakültesi Dergisi, 10(1):155-170.

Salton, J. G., \& Fuhrmann, E.C. (1999). Enhancing and Expanding "Six Hat" Thinking with Organizational Engineering. Journal Of The Organization Practitioner Development Network, 31(3),1-8.

Seymour, B., Kinn, S., \& Sutherland, N. (2003). Issues And Innovations In Nursıng Practice Valuing both critical and creative thinking in clinical practice: narrowing the research-practice gap?. Journal of Advanced Nursing, 42(3), 288-296.

Taie, S. E., \& Kamel E. A., (2013). Six Thinking Hats As A Creative Approach In Managing Meetings In Hospitals. Journal of Nursing Education and Practice, 3(9):187-200.

Wegerif, R. (2007). Teaching Thinking: Metaphors and Taxonomies. Dialogic Education and Technology, 7: 125-157.

Yenilmez, K., \& Yolcu, B. (2007). Öğretmen Davranışlarının Yaratıcı Düşünme Becerilerinin Gelişimine Katkısı. Sosyal Bilimler Dergisi, 18:95105.

| Kastamonu Eğitim Dergisi, 27(4), 2019| 